\title{
The Nature of and Motive for Academic Research in Higher Education: A sub-Saharan African Perspective
}

\author{
Muhamadi Kaweesi, Ronald Bisaso and Betty Akullu Ezati
}

\begin{abstract}
While research-led universities emphasise the importance of knowledge production in diverse fields, there is a paucity of research on the nature of scientific knowledge and researchers' motives in research-led sub-Saharan African universities. This empirical study drew on lead researchers' perspectives and documentary evidence to examine the nature of and motive for academic research across disciplinary fields in Uganda's Makerere University. Data were collected using semi-structured interviews and triangulated with document checks. Thematic analysis was used to analyse the data and Hakala and Ylijoki's knowledge production framework was employed as an analytical lens. The findings show that, despite the fact that researchers at Makerere University are generating knowledge that is useful to policymakers, civil society, the corporate sector and society at large, the emphasis is on scientific research that can be published in refereed journals so as to earn promotion. Furthermore, knowledge production takes place in a highly institutionalised and resource-constrained environment, resulting in the donor community setting the research agenda. Based on these findings, it is recommended that universities rethink the promotional assessment model, diversify research funding and apply more selective criteria in collaborating with donors.
\end{abstract}

AвOUt THE AUthors: MUHAMADI KAWEESII Senior Lecturer, Department of Educational Management and Administration, Islamic University in Uganda, Mbale, Uganda. Email: Ahmedkaweesig8@gmail.com

RONALD BISASo Associate Professor, Senior Lecturer and Dean, East African School of Higher Education Studies and Development, College of Education and External Studies, Makerere University, Kampala, Uganda

BeTty AKullu EZATi, Associate Professor, Senior Lecturer and Dean, School of Education, College of Education and External Studies, Makerere University, Kampala, Uganda 
Key words: knowledge production, academic research, research-led university, research orientation

Alors que les universités qui se concentrent sur la recherche mettent en avant l'importance de la production de savoirs dans divers domaines, on observe une pénurie de recherche sur la nature du savoir scientifique et sur les motivations des chercheurs et chercheuses dans les universités d'Afrique sub-Saharienne tournées vers la recherche. Cette étude empirique s'est fondée sur les perspectives de chercheurs principaux et des preuves documentaires pour examiner la nature et les motivations pour la recherche académique dans tous les champs disciplinaires de l'Université Makere en Ouganda. Des données ont été récupérées en utilisant des entretiens semi-guidés et ces données ont été recoupées avec des vérifications de documents. Une analyse thématique a été utilisée pour analyser les données et le cadre de production de savoirs développé par les chercheuses Hakala et Ylijoki a servi de grille d'analyse. Les résultats démontrent que, malgré le fait que les chercheurs et chercheuses à l'Université Makere produisent des savoirs utiles pour les législateurs, la société civile, le secteur des entreprises et la société dans son ensemble, l'emphase est mise sur la recherche scientifique qui peut être publiée dans des revues scientifiques dotées d'un comité de lecture, dans une perspective d'avancement de carrière. En outre, la production de savoirs a lieu dans un environnement hautement institutionnalisé et contraint par les ressources disponibles, ayant pour conséquence un programme de recherche établi par la communauté des donateurs. A partir de ces résultats, il est recommandé que les universités repensent le modèle d'évaluation promotionnel, qu'elles diversifient les financements de la recherche et qu'elles mettent au point des critères plus sélectifs dans la collaboration avec les donateurs.

\section{Introduction}

Academic research is widely recognised as a source of competitive advantage, prompting many universities to adopt it as a core strategy (Castells, 2004). However, research is influenced by the wider environment in which it occurs (Lechuga and Lechuga, 20I2). Recent changes that have impacted on academic research and researchers' motives for engaging in it include enhanced industry-university collaboration (Laursen, Reichstein and Salter, 2008), heightened emphasis on the social relevance of academic research (Cherney, Head, Povey, Boreham and Ferguson, 2013), and the need for research to promote innovation (Pamfie, Guisca and Bumba, 2014).

\section{The Research Gap}

Several studies have explored the nature of and motive for research in Higher Education (HE) (Pamfie et al., 20I4; Cherney et al., 20I3; Reddy,
20II; Ylijoki et al., 20II; Laursen et al., 2008; Hakala and Ylijoki, 200I; Nowotny, Scott, and Gibbons, 200I). These works conceptualise such research in terms of its social relevance and as a catalyst for innovation. They also note that academic research yields knowledge that informs policy making and that it promotes the professional development of academic staff. However, they were conducted in Europe and the US where Higher Education Institutions (HEIs) and the research they conduct are better endowed by government than those in developing countries.

The funding challenges confronting sub-Saharan African universities are likely to impact on the nature of and motive for undertaking academic research, resulting in different orientations from those of Western universities. Furthermore, most studies on academic research in sub-Saharan African universities tend to focus on donor approaches to research funding, collaboration, capacity building, productivity, and the broader challenges relating to research capacity (Blom, Lan, and Adil, 20I6; Kasozi, 20I6; Musiige, 20I4; Altbach, 20I3; Mouton, 20I0). A research gap thus exists in relation to how resource dependence may shape the nature of and motive for the research conducted at such institutions. This study sought to fill this gap by focusing on Makerere University.

\section{Analytical Framework}

Hakala and Ylijoki's (200I) knowledge production framework was adopted as the analytical framework to holistically explore the nature of and motive for academic research at Makerere University. The framework focuses on the intentions and audience of academic research. Its elements were articulated as sub-themes to aid analysis and interpretation of the findings. The framework is presented in Table $\mathrm{s}$ below.

Table 1. Analytical Framework

\begin{tabular}{|l|l|l|}
\hline $\begin{array}{l}\text { Research Orientation } \\
\text { (Nature of Knowledge) }\end{array}$ & Target Market & $\begin{array}{l}\text { Audience } \\
\text { (Motive for research) }\end{array}$ \\
\hline Academic/basic (Theoretical) & Academic market & $\begin{array}{l}\text { Scientific community } \\
\text { (Gaining reputation) }\end{array}$ \\
\hline Civil society (Practical) & Public market & $\begin{array}{l}\text { Ordinary people } \\
\text { (Improving practices) }\end{array}$ \\
\hline State-government (Instrumental) & Policy market & $\begin{array}{l}\text { Decision-makers ( } \\
\text { Supplying information) }\end{array}$ \\
\hline Entrepreneurial (Making profit) & Corporate market & Market forces (Commercial) \\
\hline
\end{tabular}

Source: Derived from Hakala and Ylijoki (2001) 
The framework illustrates the parameters of academic research such as the nature of the knowledge produced, the target market, the research audience, and its motive. The academic research orientation highlights the theoretical nature of knowledge that is produced to satisfy the academic market (scientific community). The civil society research orientation entails the production of practical knowledge to satisfy the public market (ordinary citizens) by improving prevailing practices. The state-government research orientation satisfies the policy market by supplying information for decision-makers. The entrepreneurial research orientation involves the generation of knowledge for commercial purposes (corporate market). The framework enabled us to interpret the unique subjective accounts provided by each participant based on their lived experiences of the phenomenon of knowledge production.

\section{Literature Review}

The nature of academic research has been the subject of intense debate among scholars. Etzkowitz and Leydesdorff (2000) assert that academic research is taking on a more applied, market-oriented entrepreneurial orientation in response to technological advancements and social demands. Other scholars contend that basic research remains important in all disciplinary fields (Wernli and Darbellay, 20I6; Ylijoki et al., 20II). Academic research has thus been dichotomised into two broad research orientations, academic (basic) and applied, each serving its audience and satisfying certain needs. Within the academic research orientation (mode I knowledge production), research satisfies the needs of the academic market. The knowledge that is produced is theoretical and researchers' main motive is to achieve recognition within the scientific community (Hakala and Ylijoki, 200I). The outcomes of this orientation are journal articles in top-ranked journals, scientific monographs and edited books (Ylijoki et al., 20II). Despite the importance of basic research, universities are under enormous pressure from governments and donors to justify the relevance of their research (Cherney et al., 20I5). Commercially-oriented, policy-relevant, and community-oriented research has thus gained traction.

Commercially-oriented research is associated with the commercial value of scientific knowledge and the growing intensity of university-industry ties (Bisaso, 20II). It aims to develop new products for which there is market demand. Such research targets the corporate market and its quality is determined by market forces (Ylijoki et al., 20II). The growing commercialisation of scientific knowledge is regarded as a long-awaited opportunity to break free from the academic/basic research orientation in order to enhance the relevance of academic research (Etzkowitz and Leydesdorff, I997). However, Slaughter and Leslie (I997) contend that, replacing basic research with market-driven research implies that academic research increasingly resembles industrial research that does not produce publicly available knowledge and serves the interests of those disciplines that are close to the market, particularly the fields characterised as 'technoscience'.

The studies reviewed above focus on Western universities. Furthermore, as noted by Boggio, Ballabeni, and Hemenway (20I6), most relied on data sourced from scientists in multiple institutions and fields (Lam, 2010; Albert, 2003; Ylijoki, 2003). We focus on a single sub-Saharan African research-led flagship institution, Makerere University.

The state-government research orientation relates to generation of knowledge for the main purpose of policy-making (Hakala and Ylijoki, 200I). The growing importance of policy-relevant research rests on recognition that scientific knowledge serves as an instrument for problem-solving, has a direct impact on the choice of a solution to a specific policy problem, serves both a policy substantiating and a policy legitimising role, and, can serve as an agenda-setter when scientific discovery unveils conditions that inform salient policy issues (Gornitzka and Sverdrup, 20I0). This study extended the body of knowledge in this area by examining the actual experiences of lead researchers at Makerere University to determine the extent to which their research is motivated by the need to inform policy.

The motivation for engaging in research that benefits civil society is to demonstrate societal relevance by producing practical knowledge to improve society and prevailing practices (Ylijoki et al., 20II). In this respect, civil society constitutes a 'fourth partner' (in addition to the university, industry, and government) and the role of the local population in economic development is recognised (Etzowitz, 2003). Reduced public funding of university research from the I990s onwards meant that academics were called on to demonstrate the social relevance of their research (Bornmann, 20I2). Today, the need for relevant knowledge is theorised in concepts such as 'mode 2 knowledge production', or the 'triple helix' and it is at the centre of universities' strategic direction (Alun and Liam, 20I4).

\section{Methods}

The study was conducted in line with the social constructivism philosophy that posits that reality is socially constructed and given meaning by people. Ontologically, we believe that there are multiple realities (Guba and Lincoln, 2005). Epistemologically, we hold that truth and meaning are created by subjects interacting with the world; hence, multiple accounts of the world can exist (Gray, 2004). We thus focused on interpreting the participants' different subjective accounts of the nature of and motive for academic research. Social constructivism was deemed appropriate to understand the nature of and motive for academic research because knowledge is produced 
through emergent social processes, implying that the focus should be on what people are thinking, feeling, and understanding, and explaining their diverse experiences rather than searching for fundamental laws to explain behaviour.

Congruent with the social constructivism philosophy, we employed qualitative methods and rooted the study in the interpretive paradigm which assumes that social life is shaped by people's experiences and social contexts (Creswell, 2007). An intrinsic case study design was used to gain a better understanding of the nature of and motive for research at Makerere University. The academic disciplines were studied as sub-units, with the aim of converging the data to gain a holistic understanding of the nature of and motive for academic research.

We stratified the University into colleges and these became analogous to combined disciplinary fields along the hard-soft and pure-applied dimensions. The selection of disciplinary fields was based on Biglan's (I973) classification of disciplines. While we ultimately selected I2 participants, as advised by Saunders, Sim, Kingstone, Baker, Waterfield, Bartlam, Burroughs, and, Jinks (20I7), the focus was not on "whether data saturation had occurred" but rather on "how much saturation was enough". Hence, in line with Jassim and Whitform (20I7), data was collected from more than I2 participants in order to confirm or validate earlier data and to guarantee that no new themes were emerging. After the i2th interview, no new themes were generated from the interviews and it was deemed that saturation had occurred. Thus, the sample size was emergent and determined posteriori but not a priori.

The I2 participants were selected from the target population as set out in Table 2 below.

Table 2. Population by Staff Rank, Disciplinary Field, Actual Sample, and Sampling Technique

\begin{tabular}{|l|l|l|l|l|}
\hline Rank & Disciplinary Field & Population & Actual Sample & Sampling Technique \\
\hline Full Profs & Hard-applied & 41 & 01 & Purposive \\
\hline Assoc. Profs & Hard-applied & 66 & O2 & Purposive \\
\hline Full Profs & Hard-pure & 08 & 01 & Purposive \\
\hline Assoc. Profs & Hard-pure & 15 & 02 & Purposive \\
\hline Full Profs & Soft-applied & 10 & 01 & Purposive \\
\hline Assoc. Profs & Soft-applied & 11 & 02 & Purposive \\
\hline Full Profs & Soft-pure & 16 & 01 & Purposive \\
\hline Assoc. Profs & Soft-pure & 28 & 02 & purposive \\
\hline
\end{tabular}

Source: Makerere University Annual Report, 2017
Eight of the selected participants were Associate Professors and four were Full Professors employed in four disciplinary fields, namely, hard-applied (medicine, engineering, and agriculture); hard-pure (chemistry, botany, and zoology); soft-applied (law, education, and economics); and soft-pure (sociology, philosophy, and anthropology). All participants that are labelled Lead Researchers were purposively selected based on their prolific contribution to knowledge production in terms of the number of publications, PhDs graduated, and grants awarded. For instance, all the Full Professors that were selected had been awarded more than ten research grants, were engaged in research projects with high levels of external funding from donors, had supervised at least ten PhD students and 20 Master's candidates and had surpassed the mandatory 2I recognised publications required by the university for promotion to Full Professor. Indeed, each had published a minimum of 50 peer-reviewed journal articles, at least two book chapters, and one book. Similarly, Associate Professors selected for this study were considered to be among the best in their field in terms of knowledge production.

Face-to-face audio recorded semi-structured interviews were conducted from March to August 20I7. The questions centred on the nature of research at the university, the major focus of the institution's research agenda and research-related policies, support for research, and the reasons for their colleges' and their own engagement in research. The interviews were manually transcribed immediately after they were conducted in order to familiarise ourselves with the data set. Given that the intention was to explore conceptualisations of the nature of and motive for academic research so as to interpret, explain and develop understanding rather than to generate theory, we used basic qualitative description and interpretation by providing straightforward accounts of the participants' understanding of academic research.

Document analysis was employed to enable triangulation and improve the validity of the findings (Yin, 20II). Document checks of the university's current strategic plan, annual reports, human resource manuals, research agendas, and research policies were based on the interview themes. The documents were obtained through website searches. Each was checked to identify the core issues related to knowledge production. This provided a context to interpret the interview data. Yin (2OII) points out that "the most important use of documents is to corroborate and augment evidence from other sources" (p. 8o).

During data analysis, we read the dataset carefully to generate initial codes. Inductive (in vivo) and deductive codes were used in the coding phase. In vivo codes, that are developed by directly examining the data (Yin, 20II), enabled us to discover patterns or the main ideas emerging from 
the data set. The actual language used by the participants was employed to generate them. On the other hand, deductive coding enabled us to use a phrase or an a priori sub-theme to represent or merge a particular chunk of data with in vivo codes. This enabled the findings to emerge while at the same time easing interpretation.

The merging of codes into categories and clustering them under a priori sub-themes was based on Bryman's (2012) observation that the researcher's own interpretations are important in qualitative research. As such, we also allowed our prior understanding of the nature of and motive for academic research based on Hakala and Ylijoki's (200I) knowledge production framework, the literature, and our own experiences to influence our interpretation. Inductive analysis was conducted based on the raw data (in vivo codes) to capture the participants' words, while the deductive analysis was based on the a priori sub-themes derived from the analytical framework, the literature, and our prior experience. This approach aligns well with the interpretive paradigm that recognises that identified patterned responses (themes) are socially produced and that prior knowledge is important in aiding interpretation (Reiner, 20I2).

To ensure confidentiality and anonymity we assigned each participant a pseudonym. Based on academic ranks, FP denotes Full Professor and AP Associate Professor. For the disciplinary categorisation, HP denotes Hard Pure, HA-Hard Applied, SP-Soft Pure, and SA-Soft Applied. In the end, the following pseudonyms were used for the Full Professorial category: FPHP, FPHA, FPSP, and FPSA. For the category of Associate Professors, the Pseudonyms were: APHPI, APHP2, APHAI, APHA2, APSPI, APSP2, APSAi and APSA2.

\section{Findings}

The presentation of the findings was guided by elements derived from Hakala and Ylijoki's (200I) knowledge production framework. They revealed that, across disciplinary fields, academic research mirrors elements that are akin to the academic, entrepreneurial, state-government and civil society research orientations. Such research has both theoretical and applied elements, suggesting that lead researchers are motivated to engage in knowledge production to satisfy the academic, corporate, policy, and public markets. Furthermore, the findings showed that, due to dependence on donor funding, the donor-driven research orientation remains dominant.

6.1 The Theoretical Nature of Research (Academic Research Orientation) Participants across disciplinary fields conceded that the nature of knowledge that is produced by academics that are still climbing the promotion ladder is largely theoretical and is motivated by the desire to publish in refereed journals so as to earn promotion. They also revealed that academics that are already Full Professors are motivated to produce theoretical knowledge because they seek to continuously extend the frontiers of knowledge so as to achieve more recognition within the scientific community. Full professors shared that:

We carry out research in order to generate new knowledge, some of which is for the purpose of getting promotion. Promotion has always been one of the major motivations for engaging in knowledge production in the College of Natural Sciences (FPHP).

When people are coming up with research proposals, they are not mindful that their research proposal must have an academic track, a problematic track, and a practice track and that they are going to be measured by those parameters. People are busy trying to surprise you with publications because it is all about promotion (FPSP).

Associate professors concurred:

The university rewards people for their innovativeness in research via promotion. The only way you can be promoted is through research and publication. My general impression is that many people have published, but this has not actually been transformed into impacting policymaking because the main aim of doing research is to publish and be promoted through the various ranks of the university (APSAI).

Promotion is a major driving factor for doing research. A person will know that in order for me to become an Associate Professor, I need five publications. So the aim will be to get the five publications, whether the outcomes from the research to these publications have application or not, he [sic] does not mind. His [sic] interest is in the promotion (APHAI).

It is evident that the majority of the academics across disciplinary fields are primarily motivated to engage in knowledge production in order to climb the promotion ladder and enjoy the benefits that come with promotion such as salary increments. Codes that supported this included 'salary increment', 'invited to conferences', 'earning income', 'increase your pay as you get the promotion', and 'earn the professorial rank'. A perusal of the Human Resource Manual (Makerere University, 2009a) and the amended policy on appointment and promotion of academic staff (Makerere University, 2009b) revealed that staff promotions were heavily dependent on publications in peer-reviewed journals and teaching.

Participants across disciplinary fields also described academic research as a tool to extend the frontiers of knowledge and achieve recognition within the scientific community. As such, the scientific community is an important market for university research results: 
Besides promotion, we engage in research and publication to generate new knowledge some of which is for extending the frontiers of knowledge. We feel proud to extend the frontiers of knowledge, to contribute to the fund of knowledge (FPHP).

We engage in research and publication to produce knowledge that is relevant to the global scientific fraternity to advance the frontiers of knowledge. That is why we have many collaborations and linkages with universities. These collaborations help us to have research that informs the global scientific community (APHAI).

When we publish, we contribute to new knowledge in the world. We get self-fulfilment and happiness when our work is cited. We become visible. We contribute to the growth of knowledge. Then we become renowned scholars and we ... receive invitations to ... share our findings with the international community (APSA2).

I now have ... I4 articles and books [in the pipeline]. So, I am now looking beyond promotion. For now, I want to extend the frontiers of knowledge. I want to be recognised internationally (APSPI).

However, some participants expressed misgivings about such an approach. For example, APSP2 remarked:

Our research largely targets the academic audience yet our motto is 'We build for the future!' Because of our elitist thinking, we are still confined to what we call the ivory tower yet we are supposed to serve society. You get very few professors who become public yet they are supposed to be public. So generally speaking, our professors are confined to the university, to the scientific community. It is unfortunate! (APSP2).

This participant highlighted the fact that confining research to the scientific community promotes elitism and produces discipline centred knowledge that largely remains in the academic domain. While it secures the institution's position in terms of university rankings, it limits knowledge dissemination (Makerere University, 2016).

\subsection{The Commercial Nature of Academic Research (Entrepreneurial} Research Orientation)

The findings also indicated that research at Makerere University is motivated by the desire to produce new products with commercial value so as to satisfy the corporate market, promote innovation and create intellectual property (IP). This implies that academic research has to some extent been conceptualised in terms of the entrepreneurial research orientation. It was clearly evident in hard-applied fields such as engineering and agriculture. By their nature, these disciplines have easy access to this market with enormous funding prospects. The following extracts support these findings:
Our research on sanitation is helping us to come up with new products. In the course of solving the problem of the use of sewage, we are getting manure and biomass out of sewage which we use in cooking and for lighting. We are doing research for electricity distribution by designing transformers which are suitable for use by small-scale enterprises. So, we are doing a lot of applied research (APHAI).

Of course, at the back of every research we do, we are looking at innovation. Can you come up with new knowledge, something new that is going to be of useful intellectual property? Our practical orientation defines who we are. So, you expect excellence, quality and diversity and innovation. Everything that we do is done in a unique way, including research (FPHA)

Institutional support for research leading to the generation of new products with commercial value is explicit in Makerere University's policies and frameworks. For instance, the University Research Agenda (2013-2018) notes that capacity for knowledge transformation and innovation should be built by, among other things, promoting commercialisation of innovations (Makerere University, 20I3a, p.2). The Intellectual Property Management Policy also promises support for commercialisation and innovation. However, these policies have yet to be fully operationalised.

The participants cited some challenges in relation to the entrepreneurial nature of university research. APHAi remarked that:

Our research answers questions that have been posed by private companies. We work on their problems, give back the results and they apply them. But not all people are receptive to these researched interventions. There is [a] general belief that our technology is still uncivilized and does not work. So that mentality is still a challenge to us. Although many embrace our technology, we still have some that do not embrace it (APHAI).

According to FPSP, APHAI, and APHA2, one of the ways to improve acceptability is to ensure that the non-academic audience is included in problem identification. The findings also showed that the weak linkages between the university, industry, government and research institutes are a major barrier to entrepreneurial research at Makerere University:

We need to improve the linkage with the sectors that utilise our research. Different ministries and organisations should be encouraged to set up research and development offices. These should be manned by people who are competent. There should be constant interaction between the university and the communities (APSA2).

The university-industry partnership is weak. There is this thing, they call the triple helix where you have the university, government and the private sector. If we can strengthen this kind of linkage, the university 
will become more innovative and will contribute to development by ensuring that the knowledge that it creates is fully utilised (APHAI).

Some participants added that entrepreneurial research is stymied by weak IP regimes that tend to limit opportunities for commercial exploitation of knowledge generated through research:

The reason for the few innovations is that people are now redoing what other people have done but in a slightly different way. There is no originality. You are using the same methods to do a similar thing but you are only changing the environment a little bit. One wonders if our Intellectual Property management policy works (APHPI).

My general impression is that many people have published, but this work has not actually been patented. If somebody is doing work in environmental economics, he [sic] is not connected with, for example, NEMA [National Environment Management Authority]. This limits opportunities for commercial exploitation of knowledge generated through research (APSAI).

6.3 Policy-Relevant Research (State-Government Research Orientation) The majority of the respondents stated that a substantial amount of knowledge is generated to inform policy to guide governance and administration. For example, FPSA noted that:

A lot of the research done in the Law School has wide-ranging policy implications for those engaged in dispute resolution and those trying to project the future of Uganda (FPSA).

FPHA also remarked that research in his disciplinary field has always informed policy-making in the Ministry of Health:

Our malaria research answers questions that are relevant to the Ministry of Health. We have a Memorandum of Understanding with the ministry and this has helped us to answer questions that are relevant to malaria control. So, during local dissemination meetings, we share research which has policy implications. Our programme dies if our research is not immediately applicable to policy (PPHA).

APSAI and APHPI concurred that they engage in academic research to generate new knowledge that is useful for policy formulation:

As economists, we blend theory with practice. You can never be a good economist without links with the policymakers ... in key ministries.... Once you choose a topic to do research, the first question is: how is this area of research ... helping policy? How is it applicable to the policy world? (APSAI).

We generate knowledge that [informs] policy. However, the biggest problem is that ... you need funding so that you can follow up by disseminating the information. We have done a lot of work that informs policy, but we rarely disseminate it. If we don't bring this work to implementers, our research cycle stops because that extra funding required to disseminate the information is never given (APHPI).

This participant is evidently of the view that Makerere University has made some progress in as far as the generation of policy-relevant research is concerned. However, he feels that there is room for improvement with regard to funding research dissemination. This was the position held by the majority of the participants (FPHA, APHAI, APHA2, APHPI, APHP2, APSAI, and FPSP) who attributed low levels of dissemination to resource constraints and preoccupation with promotion. These findings are in sync with the Research and Innovations Policy that requires "staff to publish research findings in form of policy briefs for use by policymakers” (Makerere University, 2008b, p.8).

\subsection{Scientific Knowledge to Improve Society (Civil Society Research} Orientation)

The findings showed that, across disciplinary fields, knowledge is produced with the aim of improving society. The Makerere University Strategic Plan 2008/9-20I8/I9 (Makerere University, 2008a) states that the strategic repositioning of the institution as a research-driven university aims to enable it to focus more on the production of knowledge to improve society, support evidence-based decision-making, and drive the growth of Uganda's economy (Makerere University, 2008a, p. I3). Indeed, the majority of the participants were of the view that socially-relevant academic research is the ultimate measure of a research-led flagship university. As such, the civil society research orientation can be seen in all disciplinary groups within the university:

We are engaged in research on oil exploration because the discussion about oil is mainly on econometrics and alludes to implications for economic growth. Our concern is: what is the link between oil exploration and local communities and their lives? What are the legal issues...? We want people to discuss these issues freely. [These] are [the] questions which we need to ask as legal researchers, especially if we are concerned about the majority of the communities (FPSA).

Much of our research is community-oriented. It focuses on conservation of biodiversity, restoration of polluted habitats, and looking for biological agents that can be helpful to human beings. In our discipline, we treasure research that engages communities (FPHP).

Our research in the humanities is community-based and it's is directed at solving societal problems. We have the advantage that we are naturally more connected with the political, social, and economic aspects of society. So, in the course of doing research, we engage stakehold- 
ers and also try to solve problems out there. Somehow, communities benefit (FPSP).

However, it was established that community-oriented research has low absorptive capacity because of weak linkages between the university and user communities. It also lacks a definite funding base, resulting in passive dissemination of research outputs. As such, research results are presented to peers in the scientific community, potential users are rarely engaged, and opportunities for uptake and use in society are not optimised. In this regard, APSA2 suggested that:

We need to improve the linkage between the university and the sectors that utilise our research. Different ministries and organisations should be encouraged to set up research and development offices that should be manned by people who are competent. There should be constant interaction between the university and the communities (APSA2).

\subsection{Academic Research Skewed to Donor Interests (Donor-Driven} Research)

There was consensus among the participants that academic research is increasingly driven by donor interests:

Our research is donor-funded meaning that there is a disconnect between the research agenda and the research practice. It is difficult to talk about the university research agenda because you are neither funding it nor directing it. It is very difficult to even think that the research portfolio and the research practice at Makerere University can directly contribute to what is professed in the institutional research agenda (FPSP).

There is no money to fund university research.... donors give us... money. [Thus,] in a way, the research agenda will be drawn from the global perspective such as environmental protection, now sustainable development goals, and gender equality. We are forced to do that because the donor needs it (APHP2).

Furthermore, numerous participants (APSP2, APHA2, APHPI, APSAI, FPHP and APSA2) indicated that, in undertaking research, they are conscious of donors' presence and that university research caters for the interests of donors. APSAI said that:

In many cases, we are doing research [on]... what the donor is interested in. For example, we are doing an economic analysis of technical and vocational education, the impact after ... project intervention. We are ... in that area because that is where the resources are (APSAI).

According to FPSP, the problem lies in the fact that:

The higher education sector lacks a robust research agenda to which researchers can respond. This is because the government does not fund research. [It] makes it difficult for the university research agenda to contribute to what is actually professed in it. Our research agenda ends up answering to the interests of donors because they fund research (FPSP).

Importantly, some participants (APHPI and APHA2) noted that because university research is donor-driven, the research agenda does not effectively guide researchers in the desired direction and as such, it is somewhat irrelevant. They noted that:

When donors come here, they have already decided on what they want. They are interested in people who think like them. Professors that work with them are not bringing their innovations [to] the work, but are just fitting into the donors' research agenda. If you are working with donor funds, you are working within the project funders' objectives (APHPI).

I have written many proposals where the donors don't seem to be interested in what I am presenting because it does not fit their interests. So if you are to get donors' funds, you must align yourself to their interests and fit into the objectives of the call (APHA2).

It can thus be inferred that there is over-dependence on donor funding for the university research endeavour and that despite increased prestige and access to resources, conforming with donor requirements has had negative consequences such as undermining scholarly autonomy. In turn, this has promoted a degree of passivity. The findings also point to differences among disciplinary groups with departments in applied areas (such as engineering, medicine and economics) receiving more substantial donor funding to engage in contract research than pure areas (such as zoology, philosophy, and anthropology). The obvious benefits of generous donor funding include closer contact with the outside world; additional earnings to improve departmental resources and academics being able to significantly improve their material welfare.

The university's 20I7 Annual Report (Makerere University, 20I7) which documents all running projects undertaken by college and funding agencies shows that the major funders during the year under review included the US-based National Institutes of Health (NIH) that contributed US\$4.86 million; the Royal Government of Sweden (US\$4.43 million); NORAD/ NORHED (US\$2.87 million; the Wellcome Trust (US\$2.87 million); Master Card Foundation (US\$I.70 million); DFID-UK (US\$I.55 million); the European Union (US\$I.54 million: and Grand Challenges - Canada (US\$I.I3 million). While the Government of Uganda is supposed to fund university research, its subvention seems to be more focused on enhancing staff salaries. Moreover, a decline in internally generated resources was reported due to a drop in the number of privately sponsored students enrolling at the university (Makerere University, 20I6, p.6r). Thus, although the claim that 
research funds emanate from a variety of sources is somewhat valid, donor funding outstrips other sources.

While the findings suggest that donor-driven research undertakings may not be aligned to the university's research priorities, it is worth noting that, generally, sub-Saharan African universities' research partnerships with the traditional North are governed by legal frameworks determined at the national level to promote alignment of the research agenda with national priorities. It is therefore not surprising that some donor-funded research and collaborative research arrangements between the university and donors fit well with the institution's research priorities.

Efforts to align donor-driven research with the university's research priorities are ongoing. According to Makerere University's Strategic Plan 2008/9 -20I8/I9 (Makerere University, 2008a) and the Intellectual Property Management Policy (Makerere University, 2008c), the institution has been repositioned as a research-led university with a research portfolio that is underpinned by broader national, regional and global development frameworks and trends such as Uganda Vision 2040; the National Development Plan (NDPI and II); the National Science, Technology and Innovation Policy (2009); and the Poverty Eradication Action Plan (PEAP), among others. The university has established research coordination and management structures, and research related policies to ensure that its research agenda achieves these objectives.

The Government of Uganda has also called on HEIs, particularly universities, to produce relevant knowledge that will enable the country to compete in the knowledge economy (Government of Uganda, 20I5; 20I3, 20I0). The university's research agenda thus emphasises the need for multidisciplinary research in areas of national importance such as health, agricultural transformation, natural resources management, and climate change, education, governance, and science and technology. With support from, among others, the Swedish International Development Cooperation Agency (Sida/ SAREC), the Norwegian Agency for Development Cooperation (NORAD) and the Makerere University Walter Reed Project (MUWRP), its academics have undertaken several research projects in areas that are considered to be relevant to national development such as livestock nutrition and husbandry; malaria, HIV-AIDS, degenerative diseases such as cancer, and reproductive health; water quality management; and sustainable energy in rural development (Makerere University 20I7 Annual Report).

\section{Discussion}

The study's findings demonstrate that the nature of and motives for academic research at Makerere University are varied as lead researchers are involved in knowledge production to satisfy different research markets. The results thus demonstrate the validity of Hakala and Ylijoki's (200I) framework. This implies that the transformation thesis of academic research from mode I to mode 2 knowledge production proposed by scholars such as Massy (2009), Crespo and Dridi (2007), and, Etzkowitz and Leydesdorff (I997) needs to be revisited.

7.1 The Theoretical Nature of Research (Academic Research Orientation) The following propositions are not empirically supported by the study's findings: (I) that basic research (the mode I form of knowledge production) has been wholly replaced by applied and market-driven research (Gibbons, Limoges, Nowotny, Schwartzman, Scott, and Trow, I994); (2) that there is a radical discontinuity and break between the traditional mode of knowledge production and the mode 2 form of knowledge production (Massy, 2009; Crespo and Dridi, 2007); and (3) that basic research (mode I knowledge) has been displaced and the fundamental norms and values have been turned upside down (Feldman and Desrochers, 2004).

Instead, the study found that basic research continues to be produced at Makerere University and that it co-exists with applied research orientations. This is in line with the university's current strategic plan (Makerere University, 2008a). The institution's 20I7 Annual Report also recognises that in addition to targeting national development needs, knowledge production has targeted publication in peer-reviewed journals (Makerere University, 20I7). This finding coheres with Wernli and Darbellay's (20I6) observation that research-led universities are unlikely to adopt the notion that basic research should be entirely abandoned in the foreseeable future.

7.2 The Commercial Nature of Academic Research (Entrepreneurial Research Orientation)

Participants in applied fields acknowledged that they engage in entrepreneurial research with the aim of producing products with commercial value so as to satisfy the corporate market. They also conceded that their engagement in research is partly motivated by the desire to come up with useful IP (patents). Indeed, efforts towards commercialisation of academic research in the form of cutting-edge innovations by individual academics and the establishment of interface structures have been reported (Bisaso, 2013; Cloete, Bailey, Pillay, Bunting, and, Maassen, 20II).

These results concur with those of Clark (1998) and Slaughter and Leslie (I997) who concluded that universities are becoming more involved in the commercialisation of research as a knowledge transfer mechanism. However, despite the articulation of institutional commitments and aspirations towards commercialisation of research outputs in Makerere University's research-related policies and the institution's strategic plan, 
the study found that commercialisation in the form of break-through innovations and discoveries has yet to be fully achieved. This has been attributed to the lack of research funds and failure to synchronise research outputs with the needs of industry.

7.3 Policy-Relevant Research (State-Government Research Orientation) The results showed that research produced at Makerere University impacts policy through its focus on social justice, human rights, and governance. This is line with the 20I0 Sida Review by Freeman, Johansson, and Thorvaldsson (2010) that noted that academics at the institution had engaged in policy-informing research over the years. Similarly, the university's 2017 Annual Report shows that a number of research projects were undertaken that impacted policy, including studies on Access to Justice for Women Incarcerated with Children in Uganda; Promoting Disability Rights through Legal Education; Land Justice and Governance in Uganda; and research on animal health that focused on animal disease and public health interventions.

However, the pace at which university research filters into policy processes remains slow and the emphasis on the publication of scientific papers in peer-reviewed journals is working against the policy impact of research. It can, therefore, be concluded that the tendency to lock knowledge within the expensive confines of journals makes it inaccessible to those who would use it in policy and practice.

Previous research also found that policymakers and practitioners are generally unaware of such academic works, seldom read them, and find journal articles difficult to comprehend (Katy et al., 20I6; Barwick et al., 20I4). There is, therefore, a need to ensure that the knowledge disseminated in journal articles is summarised, contextualised, and transformed so that it is presented to policymakers and practitioners in a comprehensible manner (Gagnon, 20I6). Simplification of knowledge for easy uptake could be enhanced by the use of policy briefs, newsletters, policy advice, posters, magazines, stickers, booklets, and technical reports. Publishing research findings in peer-reviewed journals should, therefore, be seen as a means to an end, the end being further development of knowledge through transforming it so that what is contained in journal articles is turned into functional knowledge for use in policy and practice.

\subsection{Academic Research to Improve Society (Civil Society Research} Orientation)

The study participants reported that engagement in community-oriented research across disciplinary fields was among the strategies adopted to enhance research uptake. Different disciplinary fields were producing knowledge with social impact (Makerere University Annual Report, 20I3b). Nurius and Kemp (20I4) note that contemporary research models are becoming transdisciplinary, multi-level, and communityconnected, suggesting a shift from mode I to mode 2 knowledge creation as espoused by Gibbons et al. (I994).

Nonetheless, community-oriented research continues to be weak and vulnerable at Makerere University, perhaps because, as indicated by Ylijoki et al. (20II), this type of research lacks a secure funding base, resulting in passive dissemination of its results. Potential users are rarely engaged and opportunities for research uptake and use in society are not optimised. Passive dissemination strategies increase awareness of the existence of research but may not have a substantial impact on societal practice (Orem et al., 20I2). Dependence on typical scholarly strategies of dissemination such as journal publications, conferences, seminars, and workshops slows uptake (Gagnon, 2016).

\subsection{Academic Research Skewed to Donor Interests (Donor-Driven} Research)

The findings showed that knowledge production at the university has been largely motivated by the desire to access donor funding. The participants conceded that the institution's research agenda mirrors donors' interests as they fund research through academic partnerships and links that are constructed as key strategies for capacity building and international cooperation. According to the university's 20I7 Annual Report (Makerere University, 20I7), research funding from donors continues to enhance its research capacity. Although numerous donors have come on board, including NUFU - Norway; the African Academy of Sciences Nairobi; UNESCO - Paris; FFEM - France; NORAD - Norway; DANIDA, UNAIDS, NORHED, WHO-GPA, and UNDP, of late SIDA-Sweden is the biggest funder of university research. University management regards such partnerships as crucial and maintains a full directorate to liaise with donors. It also recognises the role they play in the internationalisation of the institution.

While the underlying assumption is that donors strengthen the university's research agenda through capacity building, staff development and mutually beneficial, durable and empowering partnerships, in reality, the majority of these partnerships are not based on mutual negotiations between equal partners. Gaillard (I994) observes that one of the main problems encountered in the implementation of collaborative research programmes is the asymmetry of the collaboration and the dominance of Northern partners. Nevertheless, Makerere University's research profile continues to improve due to its collaboration with genuine research part- 
ners such as the Sida Collaborative Research programme and Carnegie Corporation of New York.

\section{Conclusions}

Although basic research is popular at Makerere University, engagement in applied research was also reported. Thus, basic research may not be the primary preoccupation of university staff. Across disciplinary fields, academic research is understood in terms of basic/academic, policy-relevant, community-oriented and commercially focused research. These findings validate Hakala and Ylijoki's (200I) study which identified four motives for engaging in research, i.e., to satisfy the needs of the academic, policy, public, and corporate markets. Academics at Makerere University are therefore involved in both mode I and mode 2 knowledge production.

Despite the participants' varied understanding of the nature of and motive for academic research, the study showed that basic research continues to enjoy a firm base across academic disciplines and to co-exist alongside applied research. Thus, the transformation thesis of academic research suggested by scholars such as Smith-Doer and Verdi (20I5), Etzkowitz et al. (2000), and Slaughter and Leslie (I997) from mode I to mode 2 needs to be revisited in the context of Makerere University. This conclusion supports Clark's (I998) finding that increasing entrepreneurial activities in research do not contradict traditional academic values.

The study revealed that some researchers in applied disciplines at Makerere University feel constrained in producing research outputs that they consider would have high impact due to pressure to publish in highlyrated journals. Despite being encouraged to disseminate their research to non-academic audiences, pressure to publish for an academic audience persists, perhaps, as argued by Hakala and Ylijoki (200I), due to the desire to improve their academic credentials. The popularity of scientific papers is also explained by the fact that at Makerere University dissemination to non-academic users is unsupported and unrewarded and is largely endorsed by rhetoric.

Understanding the nature of and motive for academic research at Makerere University requires an understanding of the broader institutional environment. Seen in this light, Hakala and Ylijoki's (200I) knowledge production framework is inadequate in explaining the nature of and motive for academic research at Makerere University. This study fills this gap by extending the analytical framework to include the donor market. It was established that engagement in policy-relevant, community-oriented, and commercially-focused research has, in part, been occasioned by the fact that the donors are demanding research which has practical outcomes. Moreover, scientific papers produced by lead researchers are published in highly-rated journals that are sponsored by donors and Northern research institutions. Thus, academic research at Makerere University is somewhat of a mirror image of the donor-driven research orientation. As such, the research arm of the university operates within a highly institutionalised environment.

\section{Recommendations}

The study's results show that both basic and applied research are conducted across disciplinary fields at Makerere University; knowledge production is mainly for career progression and largely targets the scientific community; academic research is largely donor-dependent and such external influence poses a major challenge to the concept of being a truly research-led university; and that, due to resource-dependence, scholarly autonomy across disciplinary fields has been greatly diminished. In light of these findings it is recommended that the university's promotional assessment model be reviewed. Assessment for academic promotion should be based on broader criteria, including, among other things, the number of publications and contribution to policy and the community. This will require increased autonomy so that academic research caters more for local interests than donor interests. To achieve this, the university should, among other things, only collaborate with genuine partners from the North; continue to lobby government to allocate a sizeable percentage of GDP to HE research; and establish stronger linkages with the small but growing private sector so that it increases its investment in research.

\section{References}

Albert, M. (2003). University and the market economy: The differential Impact on knowledge production in Sociology and Economics. Higher Education 45(2), I47-I87.

Altbach, P. G. (2013). Advancing the national and global knowledge economy: The role of research universities in developing countries. Studies in Higher Education 38(3), 316-330.

Aluni, J., and Liam, C. (20I4). Furthering the research impact of UCD: Report of the beyond publications committee. University College Dublin. http://hdl.handle.net/roi97/729

Barwick, M., Phipps, D., Myers, G., Johnny, M., and Coriandoli, R. (2014). Knowledge Translation and Strategic Communication: Unpacking differences and similarities for scholarly and research communication. Scholarly and Research Communication 5(3), I4.

Biglan, A. (I973a). The characteristics of subject matter in different academic areas. Journal of Applied Psychology 57(3), I95-203.

Bisaso, R. (20II). Utilising the Learning Organization for Management Capac- 
ity Building at Makerere University. PhD dissertation, University of Tampere.

Bisaso, R. (20I3). Academic Capitalism in the Responsiveness of Science Academic Units at Makerere University. Comparative and International Higher Education 5.

Blom, A., Lan, G., and Adil, M. (2016). Sub-Saharan Science, Technology, Engineering and Mathematics research. A decade of development. A World Bank Study.

Boggio, A., Ballabeni, A., and Hemenway, D. (20I6). Basic Research and Knowledge Production Modes: A View from the Harvard Medical School. Science, Technology, and Human Values 41(2), I63-I93.

Bornmann, L. (2012). Measuring the societal impact of research. EMBO Reports 13(8), 673-676.

Bryman, A. (2012). Social research methods. Oxford: Oxford University Press. Castells, M. (2004). The Power of Identity. The Information Age: Economy, Society and Culture. $2^{\text {nd }}$ Edition. Wiley-Blackwell.

Cherney, A., Head, B., Povey, J., Boreham, P., and Ferguson, M. (2013). Research utilization in the social sciences: A comparison of five academic disciplines in Australia. Science Communication 35(6), $780-$ 809.

Cherney, A., Head, B., Povey, J., Boreham, P., and Ferguson, M. (2015). The utilization of social science research: The perspectives of academic researchers in Australia. Journal of Sociology 51(2), 252-27IO.

Clark, B. R. (1998). Creating Entrepreneurial Universities: Organisational Pathways of Transformation. Bingley, UK: Emerald Group Publishing Limited.

Cloete, N., Bailey, T., Pillay, P., Bunting. I., and Maassen. P. (20II). Universities and Economic Development in Africa. Key findings. Cape Town: CHET.

Crespo, M., and Dridi, H. (2007). Intensification of university-industry relationships and its impact on academic research. Higher Education 54,6 I- 84 .

Creswell, J. W. (2007). Qualitative Inquiry and Research Design. Choosing among Five Approaches. SAGE Publications. Thousand Oaks, London.

Etzkowitz, H., and Leydesdorff, L. (I997). Introduction to the Special Issue on Science Policy Dimensions of the Triple Helix of University-Industry-Government Relations. Science and public policy 24(I), 2-5.

Etzkowitz, H., and Leydesdorff, L. (I998). Triple Helix as a Model for Innovation Studies (conference report), Science and Public Policy 25(3), I95-203

Etzkowitz, H., and Leydesdorff, L. (2000). The dynamics of innovation: From national systems and "Mode 2" to a Triple Helix of University- industry-government relations. Research Policy 29, I09-I23.

Feldman, M. P., and Desrochers, P. (2004). Truth for its own sake: Academic culture and Technology transfer at Johns Hopkins University. Minerva 42, 105-126.

Freeman, P., Johansson, E., and Thorvaldsson, J. (2010). Sida review: Enhancing Research Capacity at Makerere University, Uganda through collaboration with Swedish Universities, 2000-2008. Past Experiences and Future Direction.

Gagnon, M. (20I6). Knowledge dissemination and exchange of knowledge. J Orhop Sports Phys Ther 46(7), 500-50I.

Gaillard, J. F. (I994). North-South partnership: Is collaboration possible between unequal partners? Knowledge and Policy 7(2), 31-63.

Gibbons, M., Limoges, C., Nowotny, H., Schwartzman, S., Scott, P., and Trow, M. (I994). The New Production of Knowledge. The Dynamics of Science and Research in Contemporary Societies. London: Sage.

Gornitzka, A., and Sverdrup, U. (2010). Enlightened Decision Making? The Role of Scientists in EU Governance, Politique européenne 2010/3(32), I25-I49.

Government of Uganda (2009). National Science, Technology and Innovation Policy. Kampala: Ministry of Science, Technology and Innovation.

Government of Uganda (20I0). Uganda National Development Plan (NDPI) 2010/2011-2014/2015. Kampala: National Planning Authority.

Government of Uganda (2013). Uganda Vision 2040. Kampala: National Planning Authority.

Government of Uganda (20I5). Second National Development Plan (NDPII) 2015/16 2019/20. Kampala: National Planning Authority.

Gray, D. E. (2004). Doing research in the real world. London: Sage Publications.

Guba, E. G., and Lincoln, S. Y. (2005). Paradigmatic Controversies, Contradictions and Emerging Confluences. Thousand Oaks, CA: Sage.

Hakala, J., and Ylijoki, O. H. (200I). Research for Whom? Research Orientations in Three Academic Cultures. University of Tampere, Finland. Organization 8(2), 373-380.

Jassim, G. A., and Whitford, D. L. (20I7). Understanding the experiences and quality of life issues of Bahraini women with breast cancer. Social Science and Medicine 107 (2014), I89-195.

Kasozi, A. B. K. (20I6). The impact of the Uganda state management style on higher education governance, research, and post graduate training 20012012. Paper presented at a Colloquium on higher education, II April 20I6, Makerere Institute of Social Research (MISR).

Katy, S., Nigel, D., Fiona, R., and Ruth, H. (20I6). Using Twitter to drive research impact: A discussion of strategies, opportunities and 
challenges. International Journal of Nursing Studies 59, I5-26.

Lam, A. (20I0). From 'Ivory Tower Traditionalists' to 'Entrepreneurial Scientists'? Academic Scientists in Fuzzy University-Industry Boundaries. Social Studies of Science 40(2), 307-340.

Laursen, K., Reichstein, T., and Salter, A. (2008). In the know: Exploring the effect of geographical proximity on industry-university collaboration in the UK. Copenhagen Business School.

Lechuga, V. M., and Lechuga, D. C. (2OI2). Faculty motivation and scholarly work: Self-determination and self-regulation perspectives. Journal of the Professoriate 6 (2).

Makerere University (2008a). Makerere University Strategic Plan 2008/092018/19. Kampala: Makerere University.

Makerere University (2008b). Makerere University Research and Innovations Policy. Kampala: Makerere University.

Makerere University (2008c). Makerere University Intellectual Property Management Policy. Kampala: Makerere University.

Makerere University (2009a). Makerere University Human Resources Manual. Kampala: Makerere University.

Makerere University (2009b). The policy on appointment and promotion of academic staff. Kampala: Makerere University.

Makerere University (2013b). Makerere University Annual Report. Kampala: Planning and Development Department, Makerere University.

Makerere University (20I6). Makerere University Annual report. Kampala: Planning and Development Department, Makerere University.

Makerere University (20I7). Makerere University Annual report 2017. Kampala: Makerere University.

Massy, W. F. (2009). Academic values in the marketplace. Higher Education Management and policy 2(3), 1-16.

Mouton, J. (2010). The state of social science in Sub-Saharan Africa: World Social Science report. Knowledge divides Background paper, ISSC.

Musiige, G. (20I4). Research at Makerere University: Faculty perceptions towards the factors that influence research productivity. Master's dissertation, University of Oslo.

Nowotny, H., Scott, P., and Gibbons, M. (200I). Re-Thinking Science: Knowledge and the Public in an Age of Uncertainty. Cambridge, UK: Polity Press.

Nurius, P. S., and Kemp, S. P. (20I4). Transdisciplinarity and translation: Preparing social work doctoral students for high impact research. Research on Social Work Practice 24(5), 625-635.

Orem, N. J., Mafigiri, D. K., Marchal, B., Ssengooba, F., Macqi, J., and Criel, B. (2OI2). Research evidence and policy making: the perspectives of policy actors on improving uptake of evidence in health policy develop- ment and implementation in Uganda. BMC Public Health 12, Io9.

Pamfie, R., Guisca, S., and Bumba, R. (20I4). Academic research: a catalyst for innovation process within companies in Romania. Bucharest University of Economic Studies, Romania.

Reddy, P. (20II). The evolving role of Universities in Economic Development: The Case of University-Industry Linkages. In: Goransson, B., Brundenius, C. (eds) Universities in Transition. Insight and Innovation in International development, pp. 25-49. New York: Springer.

Reiner, G. M. (20I2). Understanding the differences between Husserl's (descriptive) and Heidegger's (interpretive) phenomenological research. J. Nurs Care 1, iIg.

Saunders, B., Sim, J., Kingstone, T., Baker, S., Waterfield, J., Bartlam, B., Burroughs, H., and Jinks, C. (20I7). Saturation in qualitative research: exploring its conceptualization and operationalization. Qual Quant 52(4), I893-1907.

Slaughter, S., and Leslie, L. (I997). Academic Capitalism: Politics, Policies and the Entrepreneurial University. Baltimore, MD: Johns Hopkins University Press.

Smith-Doerr, L., and Vardi, I. (2015). Mind the Gap: Formal Ethics Policies and Chemical Scientists' Everyday Practices in Academia and Industry. Science, Technology and Human Values 40(2), I76-98

Wernli, D., and Darbellay, F. (2016). Interdisciplinarity and the 21st Century Research-intensive University: Pushing the Frontiers of Innovative Research. League of European Research Universities (LERU).

Yin, R. K. (20II). Qualitative research from start to finish. New York: The Guildford Press.

Ylijoki, O-H., Lyytinen, A., and Marttila, L. (20II). Different research markets: a disciplinary perspective. Higher Education 62(6), 72I-740. 